\title{
Renal Failure due to Bardet-BiedI Syndrome
}

\author{
A Case Report
}

\author{
Sukru Ulusoy Kubra Kaynar Semih Gul Kubilay Ukinc \\ Department of Internal Medicine, Faculty of Medicine, Karadeniz Technical University, Trabzon, Turkey
}

\section{Key Words}

Bardet-Biedl syndrome $\cdot$ Renal failure $\cdot$ Hemodialysis

\begin{abstract}
Objective: To describe a case of Bardet-Biedl syndrome involving renal failure and retinal dystrophy. Case Presentation and Intervention: A 50-year-old female patient presented to the emergency service with uremic symptoms and metabolic acidosis. Polydactyly, retinitis pigmentosa, obesity, strabismus, nistagmus and renal failure were found. Because she had end-stage renal failure, hemodialysis therapy was started. She has been well for 18 months, without any complication on hemodialysis. Conclusion: Bardet-Biedl syndrome should be considered in patients with polydactyly, retinitis pigmentosa and renal failure.
\end{abstract}

Copyright (C) 2004 S. Karger AG, Basel

\section{Introduction}

Bardet-Biedl syndrome, a form of Laurence-MoonBiedl syndrome, has five recognized features: retinal dystrophy, obesity, dysmorphic extremities, renal abnormalities and hypogonadism (in male patients). Polydactyly, syndactyly or brachydactyly may be seen. The degree of polydactyly, a prominent feature of this syndrome, varies from patient to patient, ranging from a wide fifth metatarsal or metacarpal to a complete sixth digit [1]. Scores on tests of intelligence are usually low. Mental retardation, polydactyly and hypogonadism are not necessarily present in female patients [2]. The autosomal recessive disorder Bardet-Biedl syndrome is heterogeneous with at least four gene loci (BBS1-4): 11q13 (BBS1), 16q21 (BBS2), 3p12 (BBS3) and 15q22 (BBS4) [3]. A fifth locus [4] and a sixth locus [5] map to chromosome $2 \mathrm{q} 31$ and chromosome 20, respectively. These alleles may act in conjunction with mutations at other BBS loci to cause or modify the BBS phenotype. The prevalence is $1: 160,000$. It usually presents between 10 and 20 years of age. The ocular defect in Laurence-Moon-Biedl syndrome involves the photoreceptor cells [6]. In addition to retinitis pigmentosa, strabismus may be observed [7]. Early otolaryngologic, audiologic, speech pathology, and dental evaluation of these individuals is recommended [8]. Bifid epiglottis [8] and disturbance of tooth formation have been reported. Hypertrophy of the interventricular septum and dilated cardiomyopathy, insulin-resistant diabetes mellitus, empty sella, clinodactyly, and congenital hepatic fibrosis can also be found. Although hypogonadism is rare in female patients, vaginal atresia, hypoplasia of uterus

\begin{tabular}{ll}
\hline KARGER & ( ) 2004 S. Karger AG, Basel \\
$1011-7571 / 04 / 0136-0380 \$ 21.00 / 0$ \\
$\begin{array}{l}\text { Fax +4161306 12 34 } \\
\text { E-Mail karger@karger.ch } \\
\text { www.karger.com }\end{array}$ & $\begin{array}{l}\text { Accessible online at: } \\
\text { www.karger.com/mpp }\end{array}$
\end{tabular}

\author{
Doç Dr. Sukru Ulusoy \\ K.T.U. Tıp Fakultesi, Ic Hastalıkları A.B.D. \\ Nefroloji Bilim Dalı Baskanı \\ TR-61080 Trabzon (Turkey)
}

Tel. +90 46237754 54, Fax +90 46232505 18, E-Mail kkaynar@yahoo.com 
and ovaries, and ectopic urethra should be sought. Uremia is an important cause of morbidity and early mortality in these patients. Structural or functional abnormalities of the kidneys can be observed. The spectrum of renal involvement can range from calyceal clubbing or cysts to diffuse renal cortical loss [9]. Light microscopy may reveal varying degrees of increase in mesangial cellularity and matrix or sclerosis of the glomerular tuft [10]. Renal disease occurs in $70 \%$ of the patients [10].

We describe a patient with renal failure, who had signs and symptoms of Bardet-Biedl syndrome.

\section{Case Report}

A 50-year-old single, nulliparous woman with normal secondary sex characteristics presented to our emergency room in September 2000 with a history of nausea, vomiting and dyspnea. She had a history of frequent urinary system infections. On examination, she was pyrexial at $38.4^{\circ} \mathrm{C}$, and had an erythematous lesion with yellowish discharge located near the vulva. Kussmaul's respiration was observed. She had been blind since aged 40. Ophthalmoscopic examination revealed bilateral retinal pigmentation and strabismus. There were bilateral scars due to amputation of a sixth toe on both feet. Hematology revealed $\mathrm{Hb} 9.9 \mathrm{~g} / \mathrm{dl}$, WBC $15 \times 10^{9} / 1$, platelets $124 \times$ $10^{9} / 1$, blood smear showed polymorphonuclear leukocytosis. Serum creatinine was $10.4 \mathrm{mg} / \mathrm{dl}$, blood urea nitrogen was $111 \mathrm{mg} / \mathrm{dl}$, calcium was $5.8 \mathrm{mg} / \mathrm{dl}$. Blood gases revealed metabolic acidosis. Methicillin-resistant Staphylococcus aureus was isolated from the culture of the lesion. Vancomycin therapy was initiated. Renal ultrasound revealed a left kidney $77 \mathrm{~mm}$ in length and $8 \mathrm{~mm}$ in parenchymal width, with increased echogenicity of parenchyma; the right kidney was $85 \mathrm{~mm}$ in length and $10 \mathrm{~mm}$ in parenchymal width. Her body mass index was $36 \mathrm{~kg} / \mathrm{m}^{2}$, and she was $150 \mathrm{~cm}$ in height. She was normotensive and had left ventricular concentric hypertrophy. There was no history of blindness, consanguinity and renal failure in her family. Her mental status assessed quantitatively was normal. She had been postmenopausal for 2 years. Her thyroid and sex hormone levels were normal. After 3 weeks of hemodialysis she was well. The lesion regressed completely. Her estimated creatinine clearance was $6 \mathrm{ml} / \mathrm{min}$. An arteriovenous fistula was created and hemodialysis 2 times weekly was initiated. She has remained well on hemodialysis for 18 months.

\section{Discussion}

In this condition death generally occurs at a considerably younger age than in the general population with renal disease frequently noted as the primary cause of or the contributing cause of death. Renal disease seems to reduce life expectancy considerably [11]. Renal transplantation appears to have a good outcome in these patients. However, after renal transplantation, morbid obesity can be observed [12]. Peritoneal dialysis has been attempted in these patients but due to infections and the hepatic involvement of the disease, frequent conversion to hemodialysis is required [13] as in this patient.

Genetic consulting should be provided for those who want to get married and be pregnant. Prenatal diagnosis may be made by ultrasound when large echogenic kidneys (which can mimic infantile polycystic kidneys) and polydactyly may be found $[14,15]$. In a prospective cohort study; 38 patients with this syndrome were identified and studied. Of these, $86 \%$ were blind, $26 \%$ being blind by the age of 13 years [16]. Our patient was blind by the age of 10. Whereas fetal lobulation and calyceal cysts/diverticula/clubbing are characteristic in this syndrome, our patient had diffuse cortical loss. This has also been reported in this syndrome [16].

\section{Conclusion}

This report illustrates the importance of the clinician considering the diagnosis of Bardet-Biedl syndrome in adults with retinal dystrophy, polydactyly and renal failure.

\section{References}

1 Moses G, Howard C, Bar-Ziv J, Dekel S, Nyska M: Epiphyseal dysgenesis in Laurence-MoonBiedl-Bardet syndrome. J Pediatr Orthop B 1998;7:193-198.

$>2$ Green JS, Parfrey PS, Harnett JD, Farid NR, Cramer BC, Johnson G, Heath O, McManamon PJ, O'Leary E, Pryse-Phillips W: The cardinal manifestations of Bardet-Biedl syndrome, a form of Laurence-Moon-Biedl syndrome. N Engl J Med 1989;321:1002-1009.
$>3$ Beales PL, Warner AM, Hitman GA, Thakker R, Flinter FA: Bardet-Biedl syndrome: A molecular and phenotypic study of 18 families. J Med Genet 1997;34:92-98.

$\checkmark 4$ Young TL, Penney L, Woods MO, Parfrey PS, Green JS, Hefferton D, Davidson WS: A fifth locus for Bardet-Biedl syndrome maps to chromosome 2q31. Am J Hum Genet 1999;64: 900-904.
$>5$ Beales PL, Katsanis N, Lewis RA, Ansley SJ, Elcioglu N, Raza J, Woods MO, Green JS, Parfrey PS, Davidson WS, Lupski JR: Genetic and mutational analyses of a large multiethnic Bardet-Biedl cohort reveal a minor involvement of BBS6 and delineate the critical intervals of other loci. Am J Hum Genet 2001;68:606-616.

6 Runge P, Calver D, Marshall J, Taylor D: Histopathology of mitochondrial cytopathy and the Laurence-Moon-Biedl syndrome. $\mathrm{Br} \mathrm{J}$ Ophthalmol 1986;70:782-796. 
7 Kobrin JL, Ternand CL, Knobloch WH, Johnson DD: Dental abnormalities as a component of the Laurence-Moon-Bardet-Biedl syndrome. Ophthalmic Paediatr Genet 1990;11:299-303.

$>8$ Urben SL, Baugh RF: Otolaryngologic features of Laurence-Moon-Bardet-Biedl syndrome. Otolaryngol Head Neck Surg 1999;120:571574.

10 Price D, Gartner JG, Kaplan BS: Ultrastructural changes in the glomerular basement membrane of patients with Laurence-Moon-BiedlBardet syndrome. Clin Nephrol 1981;16:283288.

11 Riise R: The cause of death in Laurence-MoonBardet-Biedl syndrome. Acta Ophthalmol Scand Suppl 1996;219:45-47.

$>9$ Harnett JD, Green JS, Cramer BC, Johnson G, Chafe L, McManamon P, Farid NR, PrysePhillips W, Parfrey PS: The spectrum of renal disease in Laurence-Moon-Biedl syndrome. N Engl J Med 1988;319:615-618.
Collins CM, Mendoza SA, Grisworld WR, Tanney D, Lieberman E, Reznik VM: Pediatric renal transplantation in Laurence-Moon-Biedl syndrome. Pediatr Nephrol 1994;8:221-222.

13 Roussel B, Leroux B, Gaillard D, Fandre M: Laurence-Moon-Bardet-Biedl syndrome, chronic diffuse tubulo-interstitial nephritis and liver involvement. Helv Paediatr Acta 1985; 40:405-413.
14 Gershoni-Baruch R, Nachlieli T, Leibo R, Degani S, Weissman I: Cystic kidney dysplasia and polydactyly in 3 sibs with Bardet-Biedl syndrome. Am J Med Genet 1992;44:269273.

5 Ritchie G, Jequier S, Lussier-Lazaroff J: Prenatal renal ultrasound of Laurence-Moon-Bied syndrome. Pediatr Radiol 1988;19:65-66.

16 O'Dea D, Parfrey PS, Harnett JD, Hefferton D, Cramer BC, Green J: The importance of renal impairment in the natural history of Bardet-Biedl syndrome. Am J Kidney Dis 1996; 27:776-783. 